\title{
THE EFFECT OF ORGANIC AMENDMENTS \\ FROM BRassicaceae AND Solanaceae PLANTS \\ AND TRICHODERMA HARZIANUM ON THE DEVELOPMENT \\ OF VERTICILLIUM DAHLIAE KLEB.
}

\author{
Urszula SMOLIŃSKA, Beata KOWALSKA \\ Research Institute of Vegetable Crops \\ Konstytucji 3 maja 1/3; 96-100 Skierniewice, Poland
}

Received: September 25, 2008; Accepted: December 8, 2008

\begin{abstract}
Summary
The aim of this work was to evaluate the effectiveness of plant material from Brassicaceae and Solanaceae plants, containing biologically active compounds, and antagonistic microorganisms on survival of microsclerotia and development of Verticillium wilt of eggplant. Water extracts from tomato and rapeseed plants added to the agar media showed negative effect on the development of fungus Verticillium dahliae. The most toxic effect was observed for the fresh extract from tomato green parts. The pasteurization or sterilization of extracts in an autoclave decreased their detrimental effect. The addition of water extracts from rapeseed and tomato plants also hampered growth of mycelia and development of $V$. dahliae microsclerotia on Czapek-Dox medium with cellophane. The addition of rapeseed meal, water extracts from rapeseed meal or tomato plants, significantly decreased number of $V$. dahliae propagules in the soil. Also, the inoculation of soil with antagonistic fungus Trichoderma harzianum strain PBG decreased population of $V$. dahliae in soil samples. The plant material and $T$. harzianum strain PBG had positive effect on the growth and yield of eggplants in the soil infested with microsclerotia of $V$. dahliae. However, the most beneficial effect exerted fumigation of the infested soil with Nemazin 97 XX ( $97 \%$ dazomet), used in this experiment as a reference treatment.
\end{abstract}

key words: biologically active compounds, antagonistic microorganism, eggplant, Verticillium wilt

\section{INTRODUCTION}

Verticillium dahliae Kleb. is a widely distributed fungal pathogen of many crops worldwide (Katan 2000, Vallad et al. 2005). It has a wide host range and causes serious diseases of many woody and herbaceous plants, e.g. tomato, eggplant, pepper, cruciferous plants. $V$. dahliae causes chlorosis, stunting and wilting (Vloutoglou et al. 2000, Jabnoun-Khiareddine et al. 2006). The fungus

Corresponding author:

e-mail: usmolin@inwarz.skierniewice.pl

(c) Copyright by RIVC 
forms microsclerotia, darkly pigmented resting structure (masses of melanized hyphae) which are formed in senescent and dead tissue of the host plant. $V$. dahliae microsclerotia constitute the most important structures of the pathogen in survival, because they can survive in soil for many years and are the primary source of inoculum for $V$. dahliae infection in host plants. Conidia or mycelium do not survive long time, because this fungus is a weak competitor in the soil environment. Germination of microsclerotia is highly sensitive to soil fungistasis and occurs at high nutrition levels of root exudates in the rhizosphere of host plants. Next, fungus penetrate to plant roots and invade the vascular tissues. Infection can occur at any time during the crop growth (Xiao \& Subbarao 2000). It is very difficult to evaluate the concentration of microsclerotia of $V$. dahliae in soil. In field soil microsclerotia of $V$. dahliae occur in clustered or aggregated patterns (Xiao et al. 1997). Although many microbiological media have been developed and tested to estimate microsclerotia, none of them is good enough to calculate all fungus propagules present in the soil (Kowalska \& Smolińska 2003, Gould \& Termorshuizen 2003, Kabir et al. 2004).

One of the most sensitive plant which can be used in bioassay to confirm the presence of $V$. dahliae in soil is eggplant (Solanum melongena L.) (JabnounKhiareddine et al. 2006). The first symptoms of the disease, which starts when the crop is exposed to dry conditions, is wilting and yellowing (chlorosis) of the lower leaves. The affected leaves die and the symptoms spread to younger leaves. The next stage is the wilting of the plant, which in the case of eggplants begins from one side of plant. The disease reduces plant growth and yields.

It is supposed that severity of Verticillium wilt is related to the inoculum population in soil at beginning of the growing season, but some researches were unable to demonstrate a significant correlation between inoculum density in soil and diseased plants and it is possible that the pathogen density in soil is one of many determinant of disease severity (Nagtzaam 1998). For this reason, in presented work, the microbiological analysis together with bioassay with eggplant were conducted for the purpose of evaluation of the fungus population in soil.

Thus far, the most effective method for controlling Verticillium wilt is soil disinfection by steaming or by fumigation with chemical sterilants such as methyl bromide, dazomet or metam sodium (Ślusarski 2008). However, the use of methyl bromide is forbidden in many countries from the reason of negative effect on environment. So, the other methods for reducing Verticillium propagules in soil or peat medium, even less efficient, become of increasing interest. One of this method is the use of organic materials, e.g. green manures, wastes from processed animal products as blood, bone, fish meal (Davis et al. 1996, Lazarovits at al. 2000, Lazarovits 2001, Lazarovits et al. 2001, Tenuta \& Lazarovits 2002, Gould et al. 2004, Lopez-Escudero et al. 2007). Also, to remove the pathogen propagules from soil, the extracts or residues of plants containing biologically active compounds were used (Davis et al. 1996, LopezEscudero et al. 2007). Several authors have attributed the inactivation of $V$. dahliae microsclerotia to toxic products of glucosinolates degradation released from cruciferous residues e.g. broccoli (Shetty et al. 2000). Anti-fungal activity 
of glycoalcoalkaloids tomatine present in tomato plants are known since 1948 (Fontaine et al. 1948).

Also, some attempts to decrease the number of pathogen propagules by using antagonistic bacteria (Tjamos et al. 2004) or fungi (Berg et al. 2005) were done. One of the purpose of this work was to determine the efficiency of use of Trichoderma harzianum together with organic amendments to eradicate of microsclerotia from soil. The observation of Hanson (2000) indicated that fungi from Trichoderma genera have the potential to decrease the Verticillium wilt of cotton. Biological control activity of Trichoderma may be exerted by direct antagonisms (antibiosis, parasitism) or induction of resistance or growth promoting activity (Harman 2004). It is known that some toxic volatile compounds may weaken fungal resting propagules which are more susceptible to fungal attack. The additional advantage of antagonistic Trichoderma is their resistance to toxic compounds, and also volatile products of glucosinolate degradation (Smolińska, results not published).

The aim of this work was to evaluate the effectiveness of plant material from Brassicaceae and Solanaceae plants containing biologically active compounds and antagonistic microorganisms on survival of microsclerotia and development of Verticillium wilt of eggplant.

\section{MATERIAL AND METHODS}

The pathogen Verticillium dahliae was isolated from diseased pepper plants and maintained as a culture potato dextrose medium microsclerotia in Microbiology Laboratory of the Research Institute of Vegetable Crops. To produce microsclerotia (MS), $V$. dahliae was cultivated in the liquid glucose-mineral salt medium (Dhingra \& Sinclair 1995) or on the Czapek-Dox agar with cellophane (Kowalska \& Smolińska 2003). The antagonistic fungus Trichoderma harzianum strain PBG was isolated from a field soil near Skierniewice and maintained in the collection of Microbiology Laboratory. It showed antagonistic properties towards plant pathogenic fungi (Smolińska et al. 2007). Stock cultures were maintained on the potato dextrose agar (PDA-Merck) at $5^{\circ} \mathrm{C}$; for further experiments fungus was grown for 7-10 days on PDA at $25^{\circ} \mathrm{C}$.

Rapeseed plants (Brassica napus cv. Kana) were cultivated in the experimental field at the RIVC. Tomato plants (Lycopersicon esculentum cv. Remiz) were cultivated in greenhouse. In experiments the green upper parts of plants were used. The leaves and stems were dried in a flow chamber for $24 \mathrm{hr}$ at $45^{\circ} \mathrm{C}$. Rapeseed meal (RSM) was a commercial product, obtained after oil production (Ardex, Poland).

The effect of extracts from rapeseed and tomato plants on mycelial growth of $V$. dahliae and $T$. harzianum PBG was evaluated on agar media. The plant material, tomato or rapeseed dry plants, was mixed with tap water in proportion 1:2 (wt/v). After $48 \mathrm{~h}$ the extract were poured off and added to the potato dextrose agar (PDA) at the concentration of $5 \% \mathrm{v} / \mathrm{v}$. Following types of media were prepared; 1/ with the fresh extract, 2/ with the pasteurized extract kept $10 \mathrm{~min}$. 
at $80^{\circ} \mathrm{C} ; 3 /$ with the extract sterilized in the autoclave $\left(121^{\circ} \mathrm{C}, 20 \mathrm{~min}\right.$.). The diameter of $V$. dahliae colony was evaluated after 16 days. Additionally, the effect of extracts from tomato plants and rapeseed meal (RSM) on $V$. dahliae microsclerotia formation was studied. The extract from tomato plants (prepared as above) was sterilized by filtration. The extract from RSM (48 h, 1:3 wt/v) was not filtrated because it was blocking pores. Both extracts were added to Czapek-Dox medium at a concentration of $5 \% \mathrm{v} / \mathrm{v}$. After cooling the media, sterilized cellophane foil (Sigma) on the surface of them were placed. The plug of $V$. dahliae colony $(0.5 \mathrm{~mm})$ was placed in the center of the Petri plate. After two weeks the intensity of microsclerotia formation, reflected by the level of darkness of $V$. dahliae colony was assessed on a 0-5 scale; where 0 - white colony (without black, mature microsclerotia); 5 - black colony (with many black microsclerotia).

Survival of microsclerotia of $V$. dahliae in the soil with organic amendments and T. harzianum was studied in the laboratory conditions. The field soil (pseudopodsolic, sandy-loam soil; about $60 \%$ humidity) was sieved and then 10 $\mathrm{mg} \cdot \mathrm{L}^{-1}$ of $V$. dahliae microsclerotia were added. The soil without pathogen served as a control. To the soil, artificially infested with $V$. dahliae, different organic amendments and T. harzianum strain PBG were added. To prepare RSM extract, rapeseed meal was incubated with tap water (1:3 proportion) for $48 \mathrm{hr}$. The fresh tomato plants (mainly leaves and small stems) were cut on 2-4 $\mathrm{cm}$ pieces and poured over with tap water for $48 \mathrm{hr}$. T. harzianum strain PBG was grown on PDA (Merck) medium for 10 days, afterwards the mycelium with the spores were scraped from Petri plates and mixed with water $(20 \mathrm{ml} /$ plate $)$. The suspension of the fungus $\left(20 \mathrm{ml}\right.$ contained about $\left.1 \times 10^{8} \mathrm{cfu} \cdot \mathrm{ml}^{-1}\right)$ was added to the soil at a dose of $20 \mathrm{ml} \cdot \mathrm{L}^{-1}$.

To the $15 \mathrm{~L}$ of soil $500 \mathrm{ml}$ of extract (or tap water ) was added and mixed carefully. The RSM was added at the dose of $0.5 \%(\mathrm{wt} / \mathrm{v})$. Nemazin $97 \mathrm{XX}$ ( $97 \%$ active ingredient - dazomet) was added at the recommended concentration of $250 \mathrm{mg} \cdot \mathrm{L}^{-1}$ of soil. To obtain similar level of moisture in all treatments (about $60 \%$ ), the $500 \mathrm{ml}$ of tap water was also added to all remaining treatments. Next, the soil from each treatment was placed to the three plastic pots $(5 \mathrm{~L}$ vol. each) and covered with polyethylene foil. The pots were kept at the room temperature $\left(22-24^{\circ} \mathrm{C}\right)$. The combinations were as followed:

1. soil without pathogen - control;

2. soil infested with $V$. dahliae microsclerotia ( $V$. dahliae-MS);

3. T. harzianum strain $\mathrm{PBG}(\mathrm{T})+V$. dahliae microsclerotia $(\mathrm{T}+\mathrm{MS})$;

4. tomato extract $+T$. harzianum $\mathrm{PBG}+V$. dahliae microsclerotia $(\mathrm{T}-\mathrm{Ex}+\mathrm{T}+\mathrm{MS})$;

5. extract from $\mathrm{RSM}+T$. harzianum $\mathrm{PBG}+V$. dahliae microsclerotia (RSM $\mathrm{Ex}+\mathrm{MS}+\mathrm{T})$;

6. rapeseed meal $(0.5 \%)+V$. dahliae microsclerotia (RSM+MS);

7. rapeseed meal $(0.5 \%)+T$. harzianum $\mathrm{PBG}+V$. dahliae microsclerotia $(\mathrm{RSM}+\mathrm{MS}+\mathrm{T})$;

8. Dazomet $+V$. dahliae microsclerotia (dazomet $+\mathrm{MS})$. 
To enumerate $V$. dahliae population in soil, after two weeks of incubation a sample of soil was taken from each pot and the soil was analyzed in respect to the presence of $V$. dahliae microsclerotia on the SPA medium (Kowalska \& Smolińska 2003). $10 \mathrm{~g}$ sample of soil was sterilized in $0.5 \% \mathrm{NaOCl}$ for $10 \mathrm{~s}$ and washed 3 times in sterile water. Then it was suspended in $15 \mathrm{ml}$ of sterile water, mixed and placed on 7 Petri plates with SPA medium. After 6 days of incubation at $25^{\circ} \mathrm{C}$, the soil from the surface of medium was washed off under gentle stream of tap water and the incubation was prolonged by about 7-10 days. The black fungal colony, forming microsclerotia Verticillium -like were counted.

Phytotoxic effect of organic amendments was evaluated in plastic Phytotoxit growth plates (Tigret, Poland) with mustard (Brassica juncea) as a test plant. The soil samples obtained from treatments described above were taken twice: two and six weeks after the amendments were added. The plastic plates were filled with soil (about $60 \%$ moisture) and ten seeds of mustard were placed about $0.5 \mathrm{~cm}$ from upper edge. Each plate was watered with $5 \mathrm{ml}$ of water and closed carefully. The plates were incubated in growth chamber at $25^{\circ} \mathrm{C}(14$ hour-light) and $20^{\circ} \mathrm{C}$ (10 hour dark); humidity $-90 \%$. Three growth plates were prepared for each treatment. After 10-12 days the length of roots and the fresh weight of seedling tops were evaluated.

After 6 months of incubation with organic amendments and T. harzianum strain PBG the soil from experiment above was used in bioassay with eggplants (Solanum melongena L. cv. Black Beauty). The experiment was conducted in the years 2006 and 2007 in a greenhouse. The soil from three pots $(5 \mathrm{~L}$ each) was mixed together and divided into 10 equal parts. Each of them $\left(1.5 \mathrm{dcm}^{3}\right.$ each) were placed in the plastic pot $(5 \mathrm{~L})$ and filled up with Klasmann $\mathrm{H}$ peat medium. The seedlings of eggplants were transplanted to each pot. 10 plants were prepared per one treatment. The plants were managed according to the standard agricultural practice including recommended nutrition, irrigation and plant protection. The effect of Verticillium wilt on plants was evaluated at the end of growing season, after the last fruit harvest.

All experiments conducted in this study were replicated two or three times. The data were analyzed by standard statistical procedure. Significance of differences between means was established by analysis of variance and NewmanKeuls test at $\mathrm{P}=0.05$.

\section{RESULTS AND DISCUSSION}

Water extracts from tomato and rapeseed plants added to the agar media showed negative effect on the development of $V$. dahliae. The addition of water extracts from rapeseed or tomato plants decreased mycelial growth of $V$. dahliae on potato-dextrose agar medium (Fig. 1). The most toxic effect was observed for the fresh extract from tomato green parts. The pasteurization or sterilization of extracts in an autoclave decreased detrimental effect of them, obtained from both rapeseed and tomato plants. Similar toxic effect of water extracts from Solanaceae and Brassicaceae plants was observed by Smolińska 
and Kowalska (2006) towards Botrytis cinerea, Fusarium sp., Rhizoctonia solani and Sclerotinia sclerotiorum.

The extracts used in this experiment did not affect considerably on the growth of $T$. harzianum strain PBG (Fig. 1). Small decrease of mycelial growth was observed only during first few days of experiment (results not presented). A slight sensitivity of T. harzianum to biological active compounds present in Brassicaceae and Solanaceae plants, is very beneficial because the application of plant residues or extracts did not negatively affect the antagonistic fungus in soil. Fungi belonging to the Trichoderma are very resistant to many toxic compounds and they are one of the first microorganisms appearing after fumigation of soil (Harman 2004).

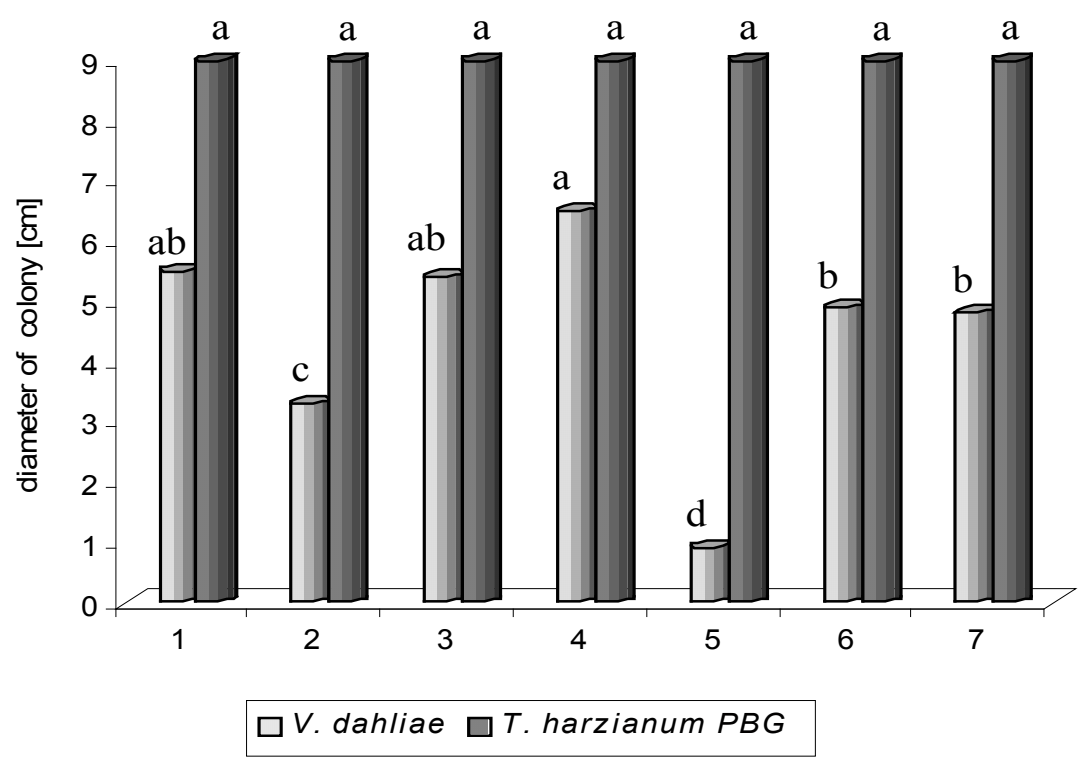

Treatments: 1/control; 2/ fresh RSM extract; 3/ sterilized RSM extract; 4/ pasteurized RSM extract; 5/ fresh tomato extract; 6/ sterilized tomato extract; 7/ pasteurized tomato extract

Note: Numbers followed by the same letter do not differed significantly at $\mathrm{P}=0.05$

Fig. 1. Growth of $V$. dahliae and $T$. harzianum PBG on the potato-dextrose medium with $5 \%$ water extracts from plant materials

The addition of water extracts from rapeseed and tomato plants also hampered mycelia growth and development of $V$. dahliae microsclerotia on CzapekDox medium with cellophane (Fig. 2). Usually, on this medium fungus grows very fast and efficiently formed small, black microsclerotia. Young colonies of $V$. dahliae at the beginning of growth form a gray-white mycelium. After about 8-10 days the fungus forms darkly pigmented resting structures which change the color of colonies to almost black. However, as it was observed in this experiment, the ability to produce microsclerotia was partially lost during growth on medium containing tomato and rapeseed meal water extracts (Fig. 2). 

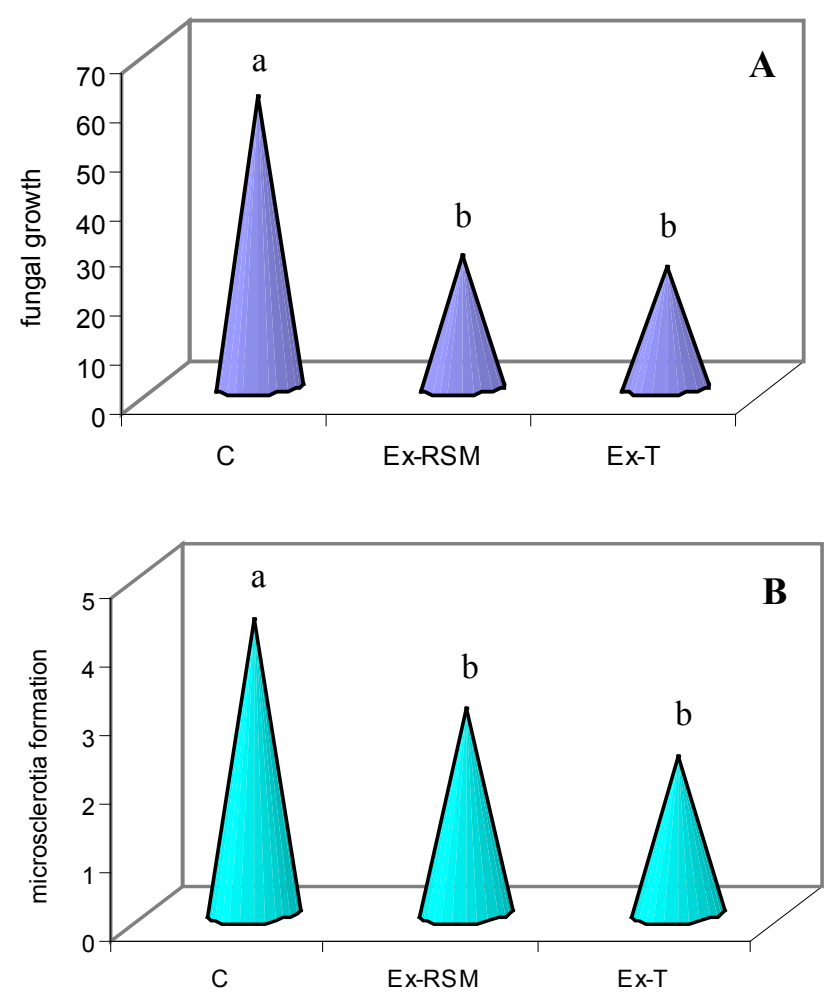

Note: see Fig. 1

Fig. 2. The effect of 5\% water extracts from rapeseed and tomato plants on the mycelial growth of $V$. dahliae (A) and intensity of microsclerotia formation on CzapekDox medium with cellophane (B)

C - control; Ex-RSM - extract from RSM; Ex T- extract from tomato plants

Fig. 2A. Fungal growth was expressed as a percent of overgrowing of medium with V. dahliae

Fig. 2B. The intensity of microsclerotia formation was expressed as a degree of darkness $V$. dahliae colony growing on Czapek-Dox with cellophane medium

The fungus growing on Czapec-Dox with extracts formed lower number of new microsclerotia and probably reduced a number of new sclerotia which became melanized. Similar effect was observed by Tjamos (2000) after sublethal heating of microsclerotia through solarization or fumigation with metam sodium. $\mathrm{He}$ concluded that sublethal heating or fumigation inactivated enzyme or enzymes involved in the production of melanin or it is responsible for melanin deposition in microsclerotia. Viable but weakened microsclerotia with reduced melanin deposition had increased susceptibility to parasitic activity of antagonistic fungus Talaromyces flavus (Tjamos 2000). V. dahliae during growing on agar media with water extracts from rapeseed and tomato residues formed more aerial hyphae with fewer microsclerotia. It is known that the ability to production of microsclerotia is often lost in agar culture due to mutational changes in mitochondrial gene controlling the production of resting structures in which the dark 
allomelanin pigments are deposited. These mutants do not survive in soil as long as wild type strains since their hyphal walls are more susceptible to parasitic activity but they can be equally as virulent as the wild type from which they are derived (Heale 2000).

Many efforts have been made to search for and use different plants material to reduce the number of fungal pathogen propagules to acceptable level. Smolińska et al. (2002) after the addition of Brassica plant residues to the soil infested with sclerotia of Sclerotium cepivorum observed a decrease in survival of these resting structures. They supposed that the lethal or sublethal effect of toxic compounds released during the decomposition of organic material, together with increased activity of microorganisms, decreased the survival of fungal pathogen. The toxic effect of plant material from Brassicaceae and Solanaceae plants towards $V$. dahliae microsclerotia present in soil was observed in the experiment conducted in laboratory conditions. The addition of rapeseed meal, water extracts from rapeseed meal or tomato plants, significantly decreased number of $V$. dahliae propagules in the soil (Fig. 3; Photo 1). Also, the inoculation of soil with antagonistic fungus T. harzianum strain PBG decreased population of $V$. dahliae in soil samples. Although in some treatments we did not obtain Verticillium colonies, however, it does not mean that this fungus was not present in the soil. Although various methods have been employed for directly quantifying of fungal propagules (Kabir et al. 2004) it is very difficult to evaluate population of this pathogen in the soil. Results obtained by authors from previous work (Kowalska \& Smolińska 2003) showed that the data from literature related to the density of $V$. dahliae microslerotia should be interpreted with caution. Methods of recovering this pathogen from soil with organic amendments are difficult and probably during the preparation of soil samples part of fungal propagules was lost.

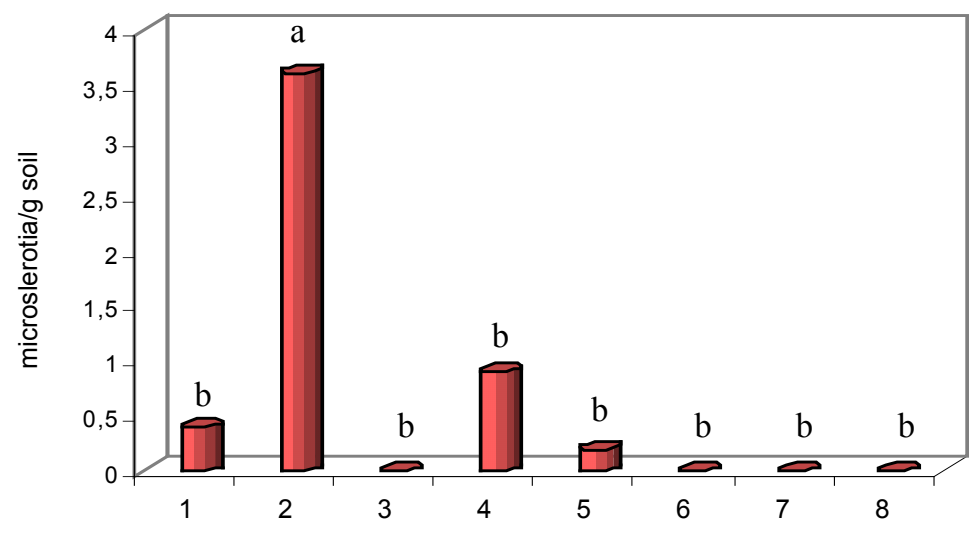

Treatments:

1/ control; 2/ V. dahliae (MS); 3/ T. harzianum $(\mathrm{T})+\mathrm{MS} ; 4 /$ tomato extract $+\mathrm{T}+\mathrm{MS}$; 5/ RSM extract + T + MS; 6/ RSM + MS; 7/ RSM + T + MS; 8/ dazomet + MS Note: see Fig. 1

Fig. 3. Survival of $V$. dahliae microsclerotia in soil amended with plant material 


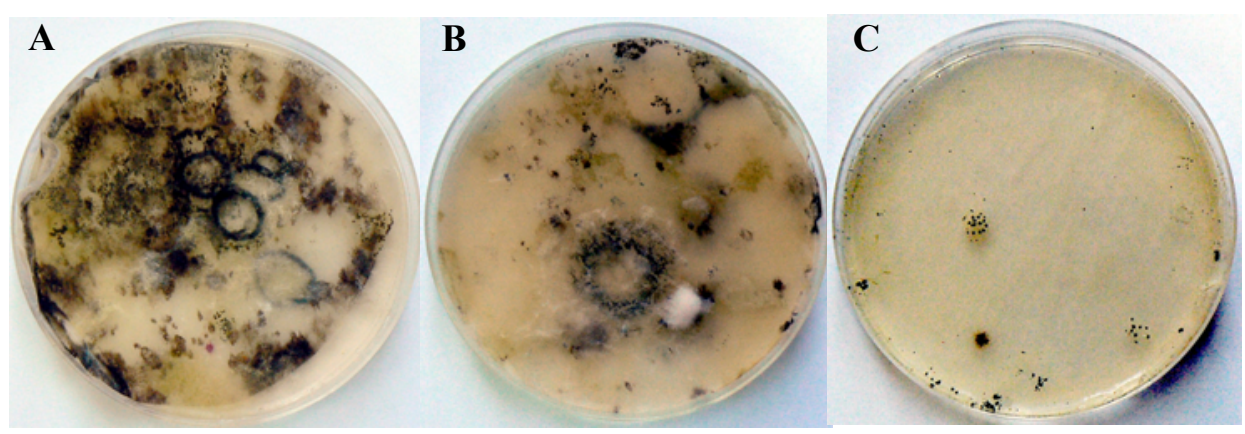

Photo 1. Isolation of $V$. dahliae on SPA medium from infested soil (A) incubated with RSM (B) or fumigated with dazomet (C)

It is known that during the decomposition of organic material in soil many phytotoxic compounds are released, especially during the first days after application. To exclude the negative influence of organic material from Brassicaceae and Solanaceae plants and T. harzianum strain PBG on eggplant plants, the biotests in plastic growth plates (Tigret) with $B$. juncea as a test plant were conducted. The negative effect of amendments towards mustard was observed after two weeks of incubation (Table 1). In the combination with dazomet none of the seeds of mustard germinated after this time. After two weeks the rapeseed meal (RSM) and T. harzianum had also the negative effect on seedlings development. On the contrary, the water extract from RSM increased significantly the growth of mustard. However, after six weeks we did not observe a negative influence of amendments on B. juncea and the beneficial effect of decomposition of rapeseed meal on the mustard was still evident. The results obtained from these experiments showed that each addition to the soil did not influence negatively an eggplant growing in the soil with organic amendments and antagonistic fungi.

Table 1. The phytotoxic effect of organic amendments on growth of mustard (Brassica juncea) used as test plant

\begin{tabular}{lcccc}
\hline \multirow{2}{*}{ Treatments } & \multicolumn{2}{c}{$\begin{array}{c}\text { Weight of seedlings from } \\
\text { one growth plate }(\mathrm{mg})\end{array}$} & \multicolumn{2}{c}{ Length of roots $(\mathrm{cm})$} \\
\cline { 2 - 5 } & Two weeks * & Six weeks* & Two weeks & Six weeks \\
\hline Control & $510 \mathrm{bc}$ & 890 & $5.61 \mathrm{ab}$ & 6.93 \\
V. dahliae (MS) & $530 \mathrm{bc}$ & 550 & $5.93 \mathrm{ab}$ & 6.63 \\
$\mathrm{~T}+\mathrm{MS}$ & $360 \mathrm{bcd}$ & 700 & $5.20 \mathrm{ab}$ & 6.60 \\
$\mathrm{~T}-\mathrm{Ex}+\mathrm{T}+\mathrm{MS}$ & $690 \mathrm{ab}$ & 760 & $6.07 \mathrm{ab}$ & 6.63 \\
RSM-Ex + T + MS & $900 \mathrm{a}$ & 890 & $6.53 \mathrm{a}$ & 6.43 \\
RSM + MS & $210 \mathrm{cde}$ & 1200 & $3.25 \mathrm{~b}$ & 7.17 \\
RSM + T + MS & $120 \mathrm{de}$ & 1050 & $5.07 \mathrm{ab}$ & 7.13 \\
Dazomet + MS & No growth & 830 & No growth & 6.4 \\
\hline LSD $_{0.05}$ & \multicolumn{5}{c}{ n.s. } \\
\hline
\end{tabular}

Note: see Fig. 1 
* The time after the addition of amendments to soil

The plant material and T. harzianum strain PBG had positive effect on the growth and yield of eggplants in the soil infested with microsclerotia of $V$. dahliae (Fig. 4). However, the most beneficial effect exerted fumigation of the infested soil with dazomet (tetrahydro-3,5-dimethyl-perhydro-3,5-thiadiazine-2thione), used in this experiment as chemical control. This agent is recommended to the growers for a complex soil disinfestation. Among biological treatments the most positive effect on eggplants showed the extract from tomato and rapeseed meal (RSM) at the dose of $0.5 \% \mathrm{wt} / \mathrm{wt}$.

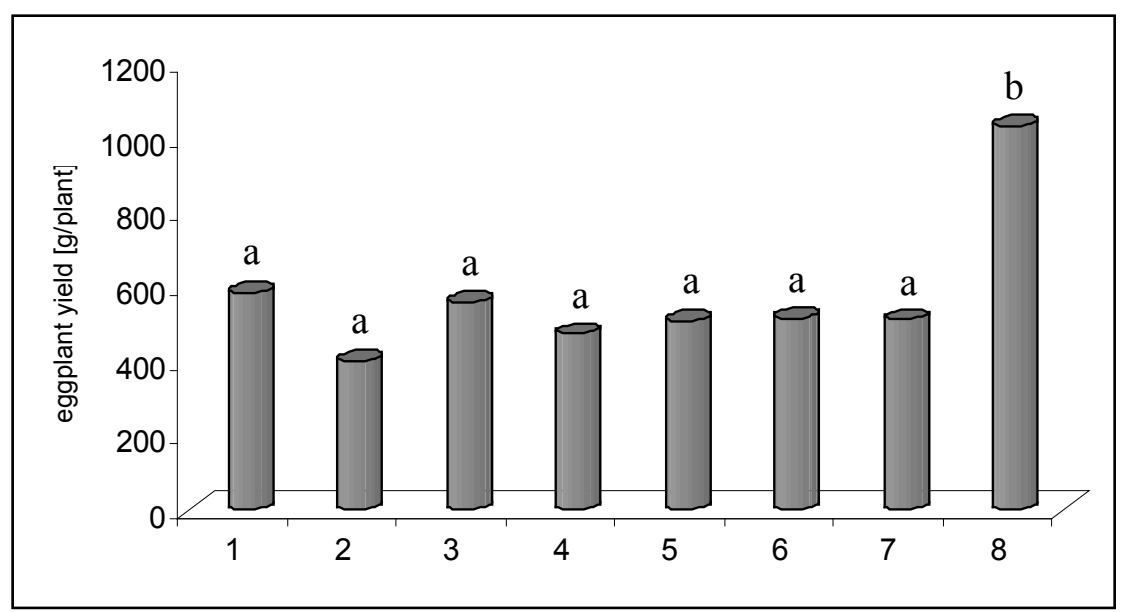

Treatments: $1 /$ control; 2/ MS; 3/ T-Ex + MS + T; 4/ Ex-RSM + MS + T; 5/ T + MS; 6/ RSM + MS; 7/ RSM + MS + T; 8/ dazomet + MS

Note: see Fig. 1

Fig. 4. The yield of eggplant grown in soil infested with $V$. dahliae microsclerotia, amended with plant material and T. harzianum $\mathrm{PBG}$

The results obtained in this work showed that both organic materials, from Brassicaceae and Solanaceae plants and antagonistic fungus T. harzianum PBG, exerted a negative effect towards fungal pathogen $V$. dahliae and affected positively the growth of eggplants cultivated in infested soil.

\section{REFERENCES}

Berg G., Zachow C., Lottmann J., Gotz M., Costa R., Smalla K. 2005. Impact of plant species and site on rhizosphere-associated fungi antagonistic to Verticillium dahliae Kleb. Appl. Environ. Microbiol. 71: 4203-4213.

[DOI: 10.1128/AEM.71.8.4203-4213.2005]

Davis J.R., Hiusman O.C., Westermann D.T., Hafez S.L., Everson D.O., Sorensen L.H., Schneider A.T. 1996. Effects of green manures on Verticillium wilt of potato. Phytopathology 86: 444-453.

Dhingra O.D., Sinclair J.B. 1995. Basic plant pathology methods. Lewis Publishers. Boca Raton London Tokyo: 352. 
Fontaine T.D., Irving G.W., Jr., R. Ma, Poole J.B., Doolittle S.P. 1948. Isolation and partial characterization of crystalline tomatine, an antibiotic agent from the tomato plant. Arch. Biochem. 18: 467-475.

Gould J.C., Termorshuizen A.J., Blok W.J., Bruggen A.H.C. 2004. Long-term effect of biological soil disinfestations on Verticillium wilt. Plant Dis. 88: 688-694.

Gould J.C., Termorshuizen A.J. 2003. Quality of methods to quantify microsclerotia of Verticillium dahliae in soil. Eur. J. Plant Pathol. 109:523-534.

[DOI: 10.1023/A:1024745006876]

Hanson L. 2000. Reduction of Verticillium wilt symptoms in cotton following seed treatment with Trichoderma virens. J. Cotton Sci. 4: 224-231.

Harman G.E. 2004. Trichoderma species-opportunistic, avirulent plant symbionts. Nat. Rev. Microbiol. 2: 43-56.

Heale J.B. 2000. Diversification and speciation in Verticillium - an overview. In: Advances in Verticillium research and disease management. (Tjamos E.C., Rowe R.C., Heale J.B., Fravel D.R. ed.), APS Press, St. Paul, Minnesota, pp. 1-14.

Jabnoun-Khiareddine H., Daami-Remadi M., Hibar K., Ayed F., El Mahioub M. 2006. Pathogenecity of Tunisian isolates of three Verticillium species on tomato and eggplant. Plant Pathol. J. 5: 199-207.

Kabir Z., Bhat R.G., Subbarao K.V. 2004. Comparison of media for recovery of Verticillium dahliae from soil. Plant Dis. 88: 49-55.

Katan T. 2000. Vegetative compatibility in populations of Verticillium - an overview. In: Advances in Verticillium research and disease management. (E.C. Tjamos, R.C. Rowe, J.B. Heale, and D.R. Fravel ed.), APS Press, St. Paul, Minnesota, pp. 69-86.

Kowalska B., Smolińska U. 2003. Evaluation of microbiological methods for enumeration of Verticillium dahliae in soil. Veget. Crops Res. Bull. 59: 121-130.

Lazarovits G., Conn K., Tenuta M. 2000. Control of Verticillium dahliae with soil amendments: efficacy and mode of action. pp: 274-291. In: Advances in Verticillium research and disease management. APS press, St. Paul, Minnesota.

Lazarovits G. 2001. Management of soil-borne plant pathogens with organic soil amendments: a disease control strategy salvaged from the past. Can. J. Plant Pathol. 23: 1-7.

Lazarovits G., Tenuta M., Conn K.L. 2001. Organic amendments as a disease control strategy for soilborne diseases of high-value agricultural crops. Austral. Plant Pathol. 30: 111-117.

Lopez-Escudero F.J., Mwanza C., Blanco-Lopez M.A. 2007. Reduction of Verticillium dahliae microsclerotia viability in soil by dried plant residues. Crop Prot. 26: $127-$ 133. [DOI:10.1016/j.cropro.2006.04.011]

Nagtzaam M. 1998. Biological control of Verticillium dahliae by Talaromyces flavus. $\mathrm{PhD}$ Thesis Wagheningen Agricultral University, The Netherlands.

Shetty K.G., Subbarao K.V., Huisman O.C., Hubbard J.C. 2000. Mechanism of broccolimediated Verticillium wilt reduction in cauliflower. Phytopathology 90: 305-310.

Smolińska U., Dyki B., Kwaśna H. 2002. Activity of fungi towards sclerotia of Sclerotium cepivorum as influence by cruciferous plant residues. Phytopathol. Pol. 24: 5-16.

Smolińska U., Kowalska B. 2006. The effectivity of plant extracts and antagonistic microorganisms on the growth inhibition of French bean pathogenic fungi. Veget. Crops Res. Bull. 64: 67-76.

Smolińska U., Kowalska B., Oskiera M. 2007. The effectivity of Trichoderma strains in the protection of cucumber and lettuce against Rhizoctonia solani. Veget. Crops Res. Bull. 67: 81-94. [DOI: 10.2478/v10032-007-0033-5] 
Ślusarski Cz. 2008. Alternatives for the replacement of methyl bromide as a soil fumigant in Poland. In: place methyl bromide for soil-borne pest control in East and Central Europe. Ed. R. Labrada. Food and Agriculture Organisation of the United Nations, Rome, pp. 59-94.

Tenuta M., Lazarovits G. 2002. Ammonia and nitrous acid from nitrogenous amendments kill the microsclerotia of Verticillium dahliae. Phytopathology 92: 255-264.

Tjamos E.C. 2000. Strategies in developing methods and applying techniques for the biological control of Verticillium dahliae. In: Advances in Verticillium research and disease management. APS press, St. Paul, Minnesota. pp. 227-231

Tjamos E.C., Tsitsigiannis I., Tjamos S.E., Antoniou P.P., Katinakis P. 2004. Selection of screening of endorhizosphere bacteria from solarized soils as biocontrol agents against Verticillium dahliae from solanceous hosts. Europ. J. Plant. Pathol. 110: 35-44.

Vallad G.E., Bhat R.G., Koike ST., Ryder E.J., Subbarao K.V. 2005. Weedborne reservoirs and seed transmission of Verticillium dahliae in lettuce. Plant Dis. 89: 317324. [DOI: 10.1094/PD-89-0317]

Vloutoglou I., Paplomatas E.J., Lampropoulos C.J. 2000. Differences in pathogenicity of Verticillium dahliae isolates from tomato, cotton, and watermelon. In: Advances in Verticillium research and disease management. APS press, St. Paul, Minnesota. pp. 155-159.

Xiao C.L., Hao J.J., Subbarao K.V. 1997. Spatial pattern of microsclerotia of Verticillium dahliae in soil and Verticillium wilt of cauliflower. Phytopathology 87: 325-331.

Xiao, C.L., Subbarao K.V. 2000. Effects of irrigation and Verticillium dahliae on cauliflower root and shoot growth dynamics. Phytopathology 90: 995-1004.

\section{WPŁYW ORGANICZNYCH MATERIAŁÓW Z ROŚLIN BRASSICACEAE \\ I SOLANACEAE ORAZ TRICHODERMA HARZIANUM \\ NA ROZWÓJ VERTICILLIUM DAHLIAE KLEB.}

Streszczenie

Celem badań była ocena fungitoksycznych właściwości materiałów roślinnych $\mathrm{z}$ rzepaku (Brassicaceae) i pomidora (Solanaceae), zawierających związki biologicznie aktywne, oraz antagonistycznego grzyba Trichoderma harzianum szczep PBG, w stosunku do grzybowego patogena Verticillium dahliae. Wodne ekstrakty z roślin pomidora i rzepaku dodane do pożywek agarowych hamowały wzrost kolonii grzyba. Najbardziej toksyczne właściwości wykazywał świeży wyciąg z liści i łodyg pomidora. Sterylizacja lub pasteryzacja ekstraktów znacznie zmniejszała ich fungitoksyczną aktywność. Dodatek wodnych wyciągów do pożywki Czapek-Dox z celofanem hamował także tworzenie form przetrwalnych $V$. dahliae - mikrosklerocjów. Podobnie niekorzystny wpływ wykazywały ekstrakty oraz wytłoczyny z nasion rzepaku (RSM) na przeżywalność mikrosklerocjów w glebie. Wzbogacenie gleby, sztucznie zainfekowanej mikrosklerocjami $V$. dahliae, wyciagami z pomidora lub rzepaku, wytłoczynami z rzepaku oraz antagonistycznym grzybem $T$. harzianum pozytywnie wpłynęło na plon bakłażanów uprawianych w warunkach szklarniowych. Najkorzystniejsze jednak działanie na plonowanie bakłażanów wykazywał, zastosowany w doświadczeniu do odkażania podłoża, środek Nemazin 97 XX (substancja aktywna dazomet).

This work was supported by grant no. 2P06R03629 from Ministry of Science and Higher Education. 